\title{
Mediation: Focus on Discourse Modeling
}

\author{
Olga A. Prokhorova* \\ Siberian Federal University \\ 79 Svobodny, Krasnoyarsk, 660041, Russia
}

Received 05.12.2018, received in revised form 28.12.2018, accepted 10.01.2019

Mediation is a growing activity in the resolution of conflicts, and more and more research emerge in different spheres including linguistics. The aim of the mediation discourse is to manage the process of cooperation aimed at resolving the conflict dispute thanks to the intervention of a "third neutral" - the mediator.

This article is a first step towards modeling a mediative discourse based on discursive and lingo-pragmatical approaches. All these issues have been little studied in a discursive context of mediation. The proposed model of the mediation discourse consists of two diametrically opposed fragments focused on the type of interaction: interaction with a conflict pragmatic potential (destructive fragment), interaction with a constructive pragmatic potential (constructive fragment). Moreover, each part of the discourse has a specific set of strategies and tactics that serve as an instrument for cognitive, verbal and emotional transformation of disputants in mediation process. The article also highlights the typology and particularities of the discourse participants.

Future research involves enriching this model with fine-grained components of the discourse, by identifying smaller discursive segments.

Keywords: mediation discourse, discourse modeling, pragmatics, mediator, disputants, interaction.

Research area: philology.

Citation: Prokhorova, O.A. (2019). Mediation: focus on discourse modeling. J. Sib. Fed. Univ. Humanit. soc. sci., 12(1), 117-127. DOI: 10.17516/1997-1370-0384.

\section{Introduction}

Mediation is a crucial means to reaching peaceful and agreed solutions in today's world - on an international, political, industrial, peace-keeping or social level. Processes occurring in the modern world sometimes require new and extraordinary approaches to the resolution of emerging disputes and conflicts. The demand for mediation in

(C) Siberian Federal University. All rights reserved

* Corresponding author E-mail address: oprokhorovasfu@gmail.com

This work is licensed under a Creative Commons Attribution-NonCommercial 4.0 International License (CC BY-NC 4.0). 
modern civilized society is largely linked to globalization, which contributes to the elimination of hierarchy and the growth of interconnections. This is reflected in all levels of social organization - in the family, in the world of the economy and labor, in government management practice.

Mediation means a process in which a neutral person or persons facilitate communication between the disputants to assist them in reaching a mutually acceptable agreement, or, at least, a better understanding of each party's positions, intentions, interests, motivations, and it is not aimed at helping one of the participants to win (Zartman, Touval, 1985: 31). In different domains of research - such as law, sociology, psychology, philosophy, linguistics or argumentation - an increasing number of academic publications focus on a better understanding of this growing practice and are therefore concerned with a mediation discourse: (Morasso, 2011; Hoffer, 1996; Jacobs, Aakhus, 2002; Janier, Reed, 2016, 2017; Barebina, 2012; Monogarova, 2017, etc.).

To allow for developing research further, it is crucial to have reliable data to study. Scientists, however, have difficulties in acquiring data to study institutional discourse in mediation, in particular because of its confidentiality principle. Although there is a lack of real transcripts, resources for mediation can be obtained in several ways, e.g. academic sources (using previous research), looking for mediation scripts online, professional sources (role-plays or mock mediations, discussing with practitioners). Although mock mediations do not present real disputes, but they are supposed to provide realistic data because they are generally used to train mediators (Janier, Reed, 2016: 1019). The involved empirical material in this paper includes data from media sources, and online recordings of mediation sessions and role plays.

Due to the existing interdisciplinary interest of researchers to the mediation process, the study of the mediation in the framework of discourse analysis is of particular relevance.

\section{Theoretical Framework of Discourse Modeling}

Communication modeling is the process of creating models that reflect elements of the structure and their interconnection. Models of communication are based on the goals and objectives that face the researcher and describe the process of communication from the sender of the message to its recipient. Communication in various spheres of society creates a certain set of rules for its implementation, which leads to the formation of certain types of discourses, such as political, legal, religious, medical, mediative and others. 
Linguistic models of language activities are becoming increasingly relevant research method of constructing processes of communicative interaction. The model can be the way of studying and describing the internal structure of the original (structural model), its behavior (functional model) and development (dynamic model) (Piotrovskij, 1998). We agree with V. Karasik that the model as a research construct of reality represents a research way for the study of the nature of the phenomenon on its system and functional connections both with phenomena of a general order and equal phenomena (Karasik, 2013: 6).

Modeling of any type of discourse is an integral part of its correct interpretation and a guarantee of an adequate use of its functional potential. The problem of discourse modeling is characterized by a wide range of approaches to its solution both in Russian and foreign linguistics.

Elson D.K. suggests two new approaches to the formal modeling of a narrative discourse, focusing on such key aspects, as agentive characters, goals, plans, beliefs, time, discourse coherence (Elson, 2012). Some representation models were proposed for scientific discourse: Harmsze's Model (2000); Buckingham Shum's model (Mancini, Shum, 2006). Groza T. (et al.) try to design a unified representation discourse model, focusing on the following aspects: overall structure of the model; the discourse structuring level; the set of relations used to connect the elementary discourse knowledge items; polarity (Groza et al., 2009).

Russian linguists focused on modeling of different types of discourse: integral system of institutional features that allows to distinguish certain types of discourse (Karasik, 2013); a cognitive model of business discourse (Shiryaeva, 2006); a communicative model of discourse (Oleshkov, 2012); the concept of a national communicative style (Kulikova, 2006); a model of a rhetorical metadiscourse (Golodnov, 2011); methods of discourse modeling (Plakhotnaia, 2016); discourse modeling in sociocultural aspect (Vokhrysheva et al., 2016).

This paper concentrates on modeling mediation discourse in terms of discourse theory and pragmatic analysis of a mediative interaction.

Linguistic pragmatics, based on the functional approach, is one of those areas that, through discourse analysis and modeling of the process of discursive interaction, allow studying communication relying on the synthesis of structural-semantic, formal and functional analysis. All of the above should be considered when modeling discourse as a process of a communicative activity of interacting parties within a communicative situation as a phenomenon having a linguo-pragmatical basis. When applying the 
method of analytical modeling, the main objective of the discourse research is the analysis and description of the process of transmission, perception and interpretation of information, which is carried out by means of verbal and non-verbal means. Each model is implemented on a pragmatic level according to a specific pattern, which provides a set of "components" (strategies, modules, speech acts, etc.).

Pragmatic modeling of a mediation discourse involves the basic pragmatic principles, structural elements, personal characteristics of participants, communication strategies and tactics.

Research methods employed include deductive and inductive approaches to the study of mediative communication, qualitative interpretative discourse analysis, and analytical modeling.

\section{Modeling of a mediation discourse}

We define the discourse of mediation as the management of the process of cognitive, verbal and emotional transformation of the disputants within the mediative process from a conflict to an agreement (Kulikova, Prokhorova, 2016: 102).

\section{Profiling discourse participants}

The participants in the discourse of mediation are represented by the mediator and parties in conflict. A mediator is a person or a group of people who, being a third neutral, independent party not interested in a given conflict, help the conflicting to resolve an existing dispute. All participants are equal, active or passive at different stages of the mediation discourse. The main intention of the mediator is to eliminate discursive confrontation and bring participants to a mutually beneficial agreement. The core values of the mediation discourse are defined as win-win solutions.

The problems tackled in the mediation discourse can occur in different contexts: family, labor world, communities, everyday life, etc. This type of discourse functions not only in the institutional domain, but also in everyday life, thus we consider it possible to distinguish two types of a mediative discourse: institutional and occasional.

Depending on the type of the mediation discourse, context and discursive status of the neutral party, we recognize two types of mediators: institutional and occasional. In general, perlocutionary effect of the mediator's utterances are not determined by his personal intentions, but are imposed on him by the conditions and tasks of conflicting communication.

An institutional mediator is usually an appropriately qualified specialist (lawyer, non-lawyer, psychologist, social worker), possessing special knowledge and skills in the field of a mediative communication. 
An occasional mediator is usually a self-appointed impartial person, that deescalates the situation, allowing for a possible resolution to be reached. Whenever a major dispute arises between two participants an informal, third-party mediator may be called upon in order to defuse the conflict.

"Consider the story of two men quarrelling in a library. One wants the window open and the other wants it closed. They bicker back and forth about how much to leave it open: a crack, halfway, three quarters of the way. No solution satisfies them both. Enter the librarian. She asks one why he wants the window open: 'To get some fresh air.' She asks the other why he wants it closed: 'To avoid the draft.' After thinking a minute, she opens wide a window in the next room, bringing in fresh air without a draft." (Fisher, Ury, 1981: 23).

Despite the fact that in the discursive space of mediation there are at least three participants, the number of disputants may vary depending on the situation. Participants in the conflict can take part in this process in person or nominate their representatives, who may be lawyers, relatives, and representatives of organizations. Thus, considering the above, the following types of conflicting parties can be distinguished: 1) individual / collective; 2) directly conflicting participants / representatives of conflicting participants.

\section{Discourse structure}

Mediation discourse can be divided into two main fragments depending on the type of interaction: interaction with a conflict pragmatic potential (destructive interaction), interaction with a constructive pragmatic potential (constructive interaction). Each fragment can involve from 3 to 15 smaller units, such as engagement in mediation, issues clarification and communication, agreement consummation, etc.

The destructive fragment of the mediation discourse is understood as the confrontational activity of disputants, a set of conflict strategies and tactics that determine the explicit and implicit content of the participants' behavior.

The confrontational strategy is a dominant one on this stage and is characterized by a tough confrontation of disputants, who do not want to understand each other and listen to the point of view of the opponent. It is aimed at defending personal position and winning at any cost, the opponent is perceived as a problem. The implementation of the confrontational strategy is mainly due to the tactics of discrediting the opponent, selfjustification and argumentation. The strategy we are considering may be expressed by direct and indirect speech acts of accusation, unwillingness to maintain contact with an opponent, in increased intonation and language aggression, as well as an inability to engage in constructive dialogue. 
Discrediting the opponent: “...they're nothing less than cheap pirates” (Resolution through Mediation..., 2011).

Self-justification: “...my life's been really crazy recently. So, it's not like it was my intention to stop paying my insurance <...> I'm like strapped for cash" (Mediation Training Video, 2013).

Argumentation in favor of their personal point of view: A: "We're a major player in the Russian alcohol market. We have these leading brands: Zenitskaya, Spartakskaya, Dinamovskaya - top of the market vodkas. We also have Pico Bello, which is highvolume. Well, we recently decided to relaunch our brand to make it more tuned to the public demands. We had an excellent registered trademark 'Octave" and very opportunity. We do have a license from you, people. Remember 1992? You granted us a license to use this eight-sided bottle" (Resolution through Mediation..., 2011).

The main discursive task of the mediator is to clarify disputants' standpoints and analyze all the problems. Using the analytical strategy as the leading one, the mediator helps the disputants in formulating the aspects of the conflict situation that are essential for a future solution. This strategy is realized in the main tactics: clarifying information, and modeling presuppositions.

Clarifying information: "So, Adela, give me an idea of what brings you here today, what happened?" (Mediation Training Video, 2013).

Modeling presuppositions: "Can I ask you how long have you known each other? When did you first meet?", "What would the kind of things that you had in common?", "What were the things you liked about each other or admired in each other?" (Mediation Demonstration..., 2013).

Asking questions is a very convenient interactive technique. With a question, a mediator does not commit herself or explicitly argues, but typically triggers the disputants' argumentation (Janier, Reed, 2017: 52).

Gradually a conflict is being transformed into a constructive interaction of discourse agents, characterized by a positive direction, implemented in a set of cooperative strategies and tactics, in the desire of disputants to achieve mutual understanding, to design a tolerant and polite interpersonal and inter-individual scenario. The mediator interrupts the competition cycle, emphasizing the cooperative elements of the disputants' relationship and deemphasizing the competitive ones.

The use of a cooperative strategy by all the participants of the mediation discourse leads the conflicting parties to a mutually beneficial solution, the mediator helps them in having a reasonable and effective discussion. Numerous tactics are used to subtly 
reorient the disputants away from conceptualizing the conflict as a win-lose contest and replacing it with the idea that the disputants have a joint problem to be solved together.

Focusing on common interests: Mediator: "Let me tell both of you one interesting observation. Whenever I ask you a question about the future you reply to me about the past and you're very well versed in all the injuries and hurts of the past". (Haynes, 1999).

Stimulating the search of a solution: Mediator: "Is there any other agreement you can make with him? Anything, anyway you can work with him on this?" (TenantLandlord Mediation, 2013).

Expressing consent and solidarity: "Yeah, let's move forward and try to reach a solution"; "We are interested in helping, "cause it is a nice fence"; "I value our friendship...” (Mediation: A Neighbor..., 2013).

Considering all the above-mentioned issues we propose the following model of the mediation discourse (Fig. 1).

We have modeled the discourse by means of a coarse-grained structure split into two large fragments and a series of links (strategies and tactics) connecting these parts. At a later stage, it is planned to enrich this model with fine-grained components of the discourse, by identifying smaller discursive segment types. Another remaining open

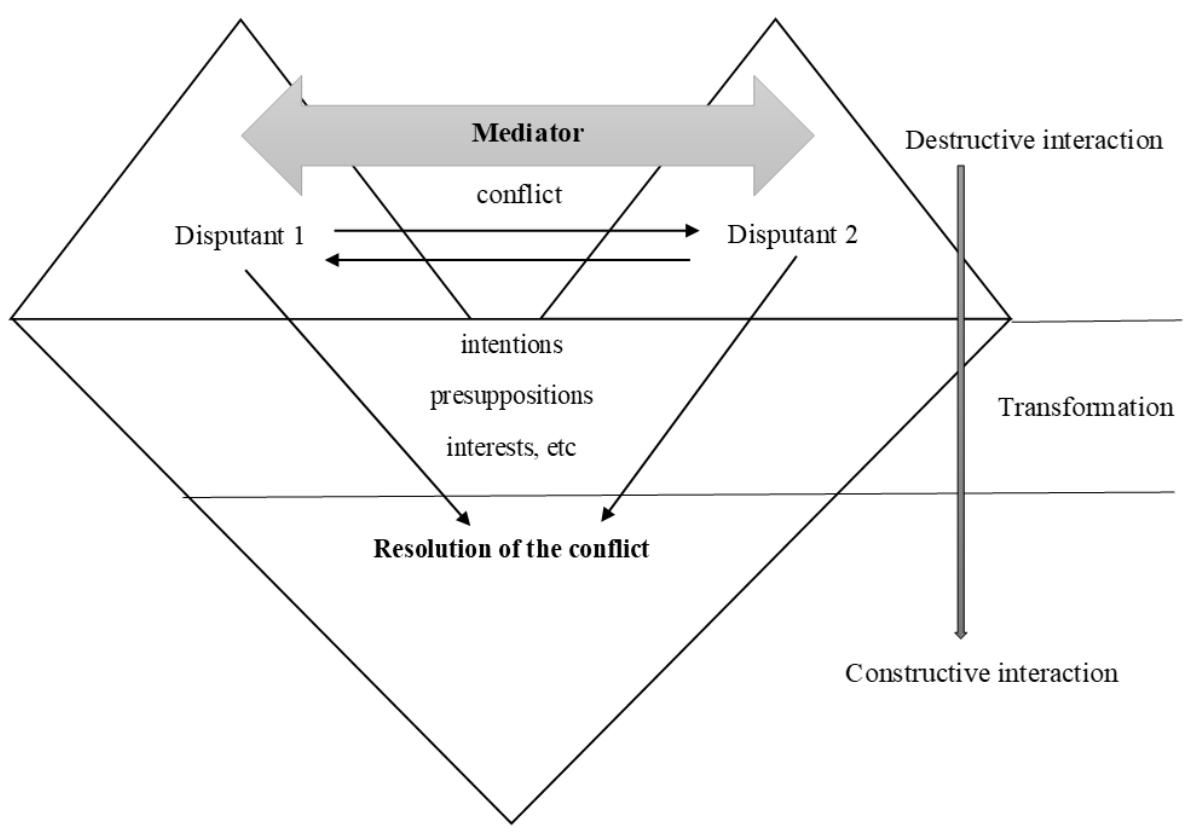

Fig. 1 
question is to find the set of pragmatic and linguistic means that make cognitive, verbal and emotional transformation of the disputants possible in the continuum of mediation. The practical evaluation of the features to be selected for the model should play a crucial role in the overall design of a mediation discourse.

\section{Conclusion}

This paper presents the very first steps towards modeling the discourse of mediation. We have highlighted some of the ingredients which are required to construct a discourse model in the framework of pragmatics and discourse analysis. This type of discourse functions not only in various spheres (law, mass-media, corporate, etc.) but in different lingo-cultural contexts (monocultural and intercultural). Each domain has different characteristics which determine peculiarities of a mediation discourse model. More mediation specificities must be explored to make sure that all the characteristics are considered. This will be part of the future work: their identification in mediation discourse will allow us to design a unified model of this type of discourse.

In conclusion we would like to mention that mediation discourse has not been subject to a lot of attention in linguistics, the study of this type of discourse requires a deep analysis from the point of view of the discourse analysis, in the cognitive, pragmatic and typological aspects.

\section{References}

Barebina, N.S. (2012). Kognitivnyi mekhanizm kontrargumentatsii v diskurse mediatsii [Cognitive Counter-Argumentation in Mediation Discourse], Irkutsk, 89 p.

Groza, T., Handschuh, S., Clark, T., Shum, S.B. (2009). A Short Survey of Scientific Discourse Representation Models. In Workshop on Semantic Web Applications in Scientific Discourse, 8th International Conference on Semantic Web, available at: http://ceur-ws.org/Vol-523/Groza.pdf

Golodnov, A.V. (2011). Ritoricheskii metadiskurs: osnovaniia pragmalingvisticheskogo modelirovaniia i sotsiokul'turnoi realizatsii (na materiale sovremennogo nemetskogo iazyka). [Rhetorical metadiscourse: the foundations of pragmalinguistic modeling and sociocultural implementation (based on the material of the modern German language)]. Ros. gos. ped. un-t im. A.I. Gertsena. Sankt-Peterburg: Asterion, 343 p.

Elson, David. K. (2012). Modeling Narrative Discourse. Columbia University, 383 p.

Fisher, R., Ury, W. (1981). Getting To Yes Negotiating Agreement Without Giving In. Random House Business Books, 90 p. 
Harmsze, F.A.P. (2000). A modular structure for scientific articles in an electronic environment. $\mathrm{PhD}$ thesis, Van der Waals-Zeeman-Institute (WZI), 253 p.

Haynes, J.M. (1999). Metaphors and Mediation, available at: http://mediate.com/ articles/metaphor.cfm.

Hoffer, D.P. (1996). Decision analysis as a mediator's tool. In Harvard Negotiation Law Review, 1, Spring, 113-137.

Jacobs, S., Aakhus, M. (2002). What mediators do with words: Implementing three models of rational discussion in dispute mediation. In Conflict resolution quarterly, 20 (2), 177-203. DOI: doi.org/10.1002/crq.19

Janier, M., Reed, C. (2016). Corpus Resources for Dispute Mediation Discourse. In Proc.10th Int. Conference on Language Resources and Evaluation, 1014-1021.

Janier, M., Reed, C. (2017). Towards a theory of close analysis for dispute mediation discourse. In Argumentation, 31 (1), 45-82. DOI: 10.1007/s10503-015-9386-y

Karasik, V.I. (2013). Iazykovaia matritsa kul'tury [Language Matrix of Culture]. M.: Gnozis, 320 p.

Kulikova, L.V. (2006). Kommunikativnij stil'v mezhkulturnoj paradigme [Communication style in intercultural paradigm]. Krasnoyarsk, 2006. 395 p.

Kulikova, L.V., Prokhorova, O.A. (2016). Issledovatel'skie podkhody k diskursu mediatsii v fokuse mezhdistsiplinarnosti [Interdisciplinary Approach to a Mediation Discourse]. In Filologicheskie nauki. Voprosy teorii i praktiki [Philological Sciences. Issues of Theory and Practice], 56 (2), 100-104.

Mancini, C., Shum, S.J.B. (2006). Modelling discourse in contested domains: A semiotic and cognitive framework. In International Journal of Human-Computer Studies, 64 (11), 1154-1171.

Mediation Training Video.mp4 (2013). Available at: https://www.youtube.com/ watch? $\mathrm{v}=\mathrm{tOpz} 2 \mathrm{bbItac}$ (accessed 25 October 2018).

Mediation Demonstration - Underlying Interests (2013). Available at: https://www. youtube.com/watch? $\mathrm{v}=\mathrm{uNx}$-WAoIlrI (accessed 20 October 2018).

Mediation: A Neighbor to Neighbor Conflict Role Play - The Mediation Process (2013). Available at: https://www.youtube.com/watch?v=KS-ykB7nYiY)/ (accessed 20 October 2018).

Morasso, G.S. (2011). Argumentation in dispute mediation. John Benjamins Publishing Company, 291 p.

Oleshkov, M.Iu. (2012). Universal'naia model' diskursa: problema paradigm [Universal Discourse Model: the problem of paradigm]. In Aktual'nye problemy 
filologii i pedagogicheskoi lingvistiki [Actual problems of philology and pedagogical linguistics], 14, 182-188.

Piotrovskij, R.G. (1998). Modelirovanie v lingvistike [Modeling in linguistics]. In Voprosy romanskogo $i$ obshhego jazykoznanija [Issues of Roman and general Linguistics], 86-96.

Plakhotnaia, Iu.I. (2016). Metody modelirovaniia diskursa [Methods of discourse modeling]. In Materialy VIII Mezhdunarodnoi nauchnoi konferentsii "Slovo, vyskazyvanie, tekst v kognitivnom, pragmaticheskom i kul'turologicheskom aspektakh" [Word, statement, text in cognitive, pragmatic and cultural aspects]. Cheliabinsk, 332-335.

Resolution through Mediation: Solving a Complex International Business Problem (2011). Available at: https://www.youtube.com/watch?v=xTbj-eHwX-w (accessed 21 October 2018).

Shiryaeva, T.A. (2006). Kognitivnaya model' delovogo diskursa: monografiya [A cognitive model of business discourse: monograph]. Izd-vo Pyatigor. gos. lingv. un-ta, $256 \mathrm{p}$.

Tenant-Landlord Mediation (2013). Available at: https://www.youtube.com/ watch? $\mathrm{v}=\mathrm{j} 6 \mathrm{JEpg} 10 \mathrm{pbw}$ (accessed 28 October 2018).

Vokhrysheva, E.V. (2016). Modelirovanie diskursa: sotsiokul'turnyi aspect [Discourse Modeling: socio-cultural aspect]. Samara: SF GAOU VO MGPU, 146 p.

Monogarova, A.G. (2017). Sovremennyi angloiazychnyi diskurs mediatsii: terminologicheskaia sostavliaiushchaia i sistema pragmaticheskikh strategii [Contemporary English discourse of mediation: terminology and pragmatic strategies], Piatigorsk, 213 p.

Zartman, I.W., Touval S. (1985). International Mediation: Conflict Resolution and Power Politics. In Journal of Social Issues, 41 (2), 27-45.

\section{Моделирование дискурса медиации}

\section{О.А. Прохорова}

Сибирский федеральнылй университет Россия, 660041, Красноярск, пр. Свободньй, 79

\footnotetext{
Медиация - это технология разрешения конфликтов, широко применяемая во всем мире. Изучение подобного вида дискурса требует глубокого исследования с точки зрения междисичилинарности, включая дискурс-анализ. Цель дискурса медиачии -управление прочессом кооперации, направленным на разрешение конфликта благодаря вмешательству «третьего нейтрального» участника - медиатора.
} 
Эта статья представляет собой первый шаг к моделированию дискурса медиации в рамках дискурсивного и лингвопрагматического подходов. Все эти проблемы мало изучены в дискурсивном пространстве медиации. Предлагаемая модель дискурса медиации включает два диаметрально противоположных фрагмента в зависимости от вида интеракиии: интеракция с конфликтным прагматическим потенциалом (деструктивный фрагмент), интеракиия с конструктивным прагматическим потеничиалом (конструктивный фрагмент). Более того, каждая часть дискурса имеет определенный набор лингвопрагматических средств, которые служат инструментом для когнитивной, вербальной и эмоциональной трансформации конфликтующих участников в проиессе медиации. В статье также проводится анализ участников дискурса, описываются прагматические стратегии и тактики.

Дальнейшие исследования предполагают выделение и анализ более мелких дискурсивных компонентов данной модели дискурса медиащии.

Ключевые слова: дискурс медиаџии, моделирование дискурса, прагматика, медиатор, конфликтующие участники, интеракиия.

Научная специальность: 10.00.00 - филологические науки. 